\author{
Бисера Јевтић \\ Филозофски факултет Нии \\ Департман за педагогију \\ e-mail: bisera.jevtic@filfak.ni.ac.rs.
}

\title{
МОРАЛ КАО ПРАКСА ПЕДАГОШКЕ ЕТИКЕ
}

Апстаркт: У овом тексту аутор разматра морал као праксу педагошке етике у духу хришћанског учења. О сложености појма најбоље говори сазнање да је историја морала дуга колико и историја друштва и да се она са развојем друштва трансформисала и постала комплекснија. У овом раду ћемо феномен моралности обрадити кроз анализу више аспеката и димензија који су у служби педагошке етике. Педагогија спада у ред оних наука које нуде богатство идеја и остварења универзалне вредности о томе како подићи дете, помоћи му да очува људску суштину и достојанство - и како данас бити хуманистичко-морална личност. Дете је свемирска тема истраживања, трајни предмет васпитања за животну борбу, за моралну узвишеност, човекољубље, родољубље и слободољубље.

Кључне речи: морал, хришћанство, вредности, васпитање, личност.

\section{Увод}

У духу хришћантва, централна тачка наше преокупације је дете-личност које треба васпитавати, неговати, штитити, отворити му перспективе, научити га да се бори за срећу других и за своју срећу, да зна подносити успехе и неуспехе и да његов животни кредо буде - никад не пропустити да учиниш добро и никад не устукнути пред злом. Ове огромне хуманистичко-моралне хришћанске задатке дужна је да оствари наука о васпитању, која је истовремено и значајна наука за државу, укупно друштво и његов прогресивни развој. Човечанство и ми нашли смо се на крају 20. века на озбиљним и изазовним раскршћима, на којима треба учинити мудар избор пута, наоружати се знањем и моралном енергијом за одговоре на сва отворена питања која друштво учења у 21. веку неумитно доноси и намеће.

Можда нам данас могу извесни Русоови погледи помоћи да видимо како тражити и заштитити дете новог доба, на размеђи миленијума. Филозоф и педагошки класик збунио је Европу свог времена када је 1749. године од дижонске Академије добио прву награду, одговоривши у свом раду на питање - да ли је напредак наука и уметности ослабио или унапредио морал?. Русо је у својој расправи у делу Емил-или о васпитању (1953) тврдио да је морал слабио што је цивилизација више напредовала, да цивилизација није донела срећу човечанству, да у тадашњој Француској владају раскош и поквареност, да је стари Рим моралнији од новог, да је Спарта била моралнија од Атине.

На другом наградном конкурсу дижонске Академије Русо је на тему "О извору неједнакости међу људима" написао расправу "Друштвени уговор" (1762) и доказао да се 
неједнакост међу људима повећавала са напредовањем цивилизације. Остаје нам, данас, да трагамо на истим путевима сазнања, за одговором на питање које је тако давно поставила дижонска Академија. (и тако луцидно одговорио Русо, тврдивши, у контексту свог доба, да друштво штетно утиче на васпитавање младих), а да су васпитачи они који адекватним методама васпитавају моралну личност.

Педагогија ренесансе детета данас је пред најсложенијим и најхуманијим хришћанским задацима да (ре)афирмише систем вредности на чијем врху сија морална личност, да помогне онима који своју младост збуњено и неразумно третирају као промашај и заблуду; да помогне и онима који данас своју младост или старост доживљавају као несрећно време и теже неком лепшем животу у туђем (лажно бајковитом) свету, да пружи руку спаса оним експресним богаташима без рада да се врате људској суштини и људима око себе, да интензивно сузбија сејаче песимизма код младих и одраслих (угрожавајући и садашњост, будућност и животе), да свим средствима и методама олакшава живот деци и младима, у складу са хришћанством, према Митрополиту Илариону Алфејеву (2009) у Беседама о хришћанском животу, као секуларним хуманизмом који говори о достојанству и слободи личности, али за разлику од потоњег, хришћанство инсистира на томе да принцип слободе мора да буде добро избалансиран са принципом личне духовне и моралне одговорности пред Богом и другим људима. Свака личност може да дефинише сопствене вредности према којима се управља у зависности од сопственог погледа на свет, жеља̂, тежњи, навика, усмерења, и свака личност има право да установи сопствене норме понашања засноване на личном поимању добра и зла. Митрополит Црногорско-приморски др Амфилохије Радовић (2002) пише: „Срж и суштина Православља, његова неуништива сила и снага јесте управо тај дивни и незаменљиви лик Христа Сина Божијег ... Основна брига Православља кроз његову дугу историју била је и остала да очува неискварени лик еванђелског Христа и да Га правилно прославља. И сама реч Православље сведочи да је оно право и правилно прослављање Христа као савршеног Бога и као савршеног човека. Шта је дакле Православље? Православље је истинско прослављање Бога у човеку и човеком, и прослављање човека у Богу и Богом; Његово прослављање не пролазном него вечном славом, оном славом коју је Бог припремио од искони онима који Га љубе. Шта је још Православље? Православље је права вера и право живљење и владање по тој вери. И једно и друго, и права вера и право живљење, откривено је и оваплоћено у чудесној личности Исуса из Назарета. Та права вера и то право живљење неодвојиви су једно од другога као што је и сам Христос нераздељив као Бог и Човек.

Када у Православној цркви размишљамо о одрастању (Живковић 2018), ми говоримо о Богу који штити, спашава, милује и чува нашу децу и нас, говоримо о цркви која није заједница одраслих већ заједница одраслих и деце, или у једном другом смислу само заједница деце, деце Божије, говоримо о односима љубави у Христу, који се манифестују и у односима са децом, који могу имати педагошког учинка, али представљају и значе много више од тога. Васпитање без идеологије практично је незамисливо.

\section{Морал-пракса етике}

Савремено човечанство доживљава најбурније промене као што се очекује да ће оне убудуће бити све бурније и бурније. Промене су толико брзе и дубоке да изазивају вртоглавицу и уносе знатне поремећаје у свакодневни људски живот. Морал је једна од појава која се данас врло брзо мења. Промене морала су утолико значајније за човека што непосредно и битно погађају његову личност, што задиру у саму њену срж. Управо ако се морал сувише брзо мења, човек доживљава неку врсту шока - његове основне 
вредности се мењају пред његовим очима, а њихове претпоставке се из основа руше, и то непосредно прети његовој душевној и духовној равнотези.

Поред промена које значе хуманизацију морала постоји и други правац промена које значе његово дехуминизирање: као врховна вредност све више избија животни (материјални) стандард уместо да то буде усавршен човек. Одговорност за оно што се чини и како се чини сваљивано је на плећа појединца и представљало основ обликовања његових карактерних црта. Тако се рађало индивидуално упориште за универзално пожељно понашање које ће од морала учинити облик вредновања људске праксе (Милосављевић 2006).

Још су стари грчки мислиоци настојали да објасне природу моралности. Неки од њих су своје етичке идеје доводили у везу са педагошким схватањима и тиме допринели развоју педагошке мисли. Међу овим филозофима нарочито се истиче Сократ. Сократ је, супротстављајући се сазнајном и етичком релативизму у учењима софиста, прогласио истину објективном. Сократ је сматрао да је човек по природи добар и да је суштина васпитања у томе да се ослободи лоших спољашњих утицаја, да упозна себе, како би знао шта је морално и како да се понаша, (према: Хорачек 2020). Онај ко упозна разлику између добра и зла чини добро, а клони се зла, али ако неко греши не чини то намерно већ из незнања. Највише сазнање није сазнање природе, него познавање самог себе. Човек треба да открије у себи оно што је стално и опште, дакле, принципе по којима треба да живи. Сократ није разликовао мудрост и моралност, мудрост је највиша врлина, јер се њоме подстичу и развијају све остале врлине. Склоност ка врлини постоји углавном код свих људи, пошто "човек сам у себи носи орган за разликовање добра и зла" (Павићевић 1974, 217). Он захтева познавање апсолутних врлина и највише је ценио знање о моралу јер је био уверен да је знање о врлинама исто што и сама врлина. Због тога је потребно да човек упозна сам себе, да дође до сазнања о сопственој несавршености које ће бити подстицај за доживотно усвршавање.

Познати римски теоретичар Марк Фабије Квинтилијан истиче (према: Ценић, Петровић 2005), говорећи о васпитању говорника, да је потребно, поред осталог, да буде потпуно поштен човек. Тиме је указао на значај речи у моралном васпитању. Квинтилијан истиче својства учитеља, и захтева да разговори буду дужи о моралном и добром, затим чешћа саветовања. Сматра да је неопходно упознати природу детета, његове индивидуалне особине и разлике, па у складу са тим адекватно поступати. Квинтилијан истиче да учитељ у свему треба да служи за пример, да буде једноставан у раду са децом, стрпљив, љубазан. Он је указао и на друга средства и услове моралног васпитања: садржај наставног рада, подстицање, дружење са вршњацима, лични пример, избор дадиље "педагога". Учење понашања може да предходи стицању знања о моралним нормама.

Педагошка мисао Јан Амоса Коменског у делу Материнска школа (2000), утемељена је на безграничној љубави према човеку. Он захтева васпитање у складу са природом детета. Потребно га је научити да правилно говори, навикнути га на рад, али му дати и основе моралности. Осим наставе која је доминантна у његовим педагошким разматрањима, Коменски се бавио и проблемима васпитања уопште. Његова пажња је усмерена на физичко васпитање, али моралном васпитању поклања још већу пажњу. Он сматра да су понизност, поштовање старијих, послушност и друге врлине важне за формирање једне личности. Од свих врлина он највише цени умереност. Осим умерености, Коменски сматра, да се деца треба учитити чистоћи и уредности, услужности, истинољубивости, праведности и поштењу, трудољубљу, уздржљивости и стрпљењу, учтивости и озбиљности у понашању, како би у својим поступцима била разумна, стидљива и штедљива. Коменски, када је у питању морално васпитање, у први план ставља деловање на децу примером, затим благовремено и опрезно упућивање у 
случајевима када пример није довољан. Ако не помогне ни добар пример, ни упућивање, Коменски предвиђа казну, и то прво блажу (узвик), а онда и строжу (замахнути руком или пљеснути рукама). Дисциплина у школи је у непосредној вези с моралом ученика. Коменски заступа став да физичке казне треба избацити, а да дисциплину треба одржавати примером и правилном организацијом рада. Улога учитеља је веома важна, потребно је да изазове код ученика интересовање за учење. Учитељ ће у томе упети уколико привуче дечја срца својом наклоношћу, пријатељским опхођењем и љубављу према детету.

Цон Лок у делу Мисли о васпитању (1967) сматра да је душа детета по природи као чиста табла (табула раса) која се исписује постепено, под утицајем искуства и васпитања. Лок се залаже за васпитање "џентлмена", који треба да буде образован, спретан, самосталан, практична духа, да поседује најнеопходнију особину, а то је врлина. Он придаје посебан значај моралном васпитању. Он сматра да је дисциплина духа у непосредној вези са моралним васпитањем. Џон Лок каже да са децом треба поступати строго, навикавати их да себе обуздавају и да буду послушна. За најважније средство васпитања, сматра, стварање навика. Са образовањем и стварањем навика треба почети у раној младости, јер се последице тог првог васпитања осећају кроз сав живот. Посебно треба бити опрезан са физичким казнама, које сматра штетним васпитним средством, али их ипак допушта када треба сломити тврдоглавост детета. Лок признаје похвалу и укор као средства васпитања, који утичу на осећање части и стида. Лок истиче поучавање са примером као васпитним средством и навикавање деце на издржљивост, на човечност, на савлађивање страха и др. Неопходно је водити рачуна о индивидуалним особинама детета и залаже се за индивидуално васпитање.

Један од првих теоретичара који је истакао својеврсност детињсва, који је истакао да се дете по својој природи разликује од одраслог јесте Жан Жак Русо. Он сматра да васпитање треба прилагодити дечјој природи. Израдио је периодизацију развоја детета од четири ступња - у делу Емил или о васпитању (1953). Морално васпитање се остварује на четвртом ступњу - од 15 . године до пунолетства. У овом периоду васпитава се млад човек за живот у друштву, за живот са другим људима. Сматра да је улога васпитача велика и незаобилазна. Он је ту да подстакне пријатељска осећања, љубав према другим људима, искреност и саосећање. "Из првих покрета срца ничу први знаци савести, а из првих осећања љубави и мржње развијају се први појмови о добру и злу" (Ценић, Петровић 2005, 134). Русо је сматрао да су младићи на овом узрасту способни за апстракције и да је могуће изучавати историју (кроз историјске примере долази се до правилних судова). Он је сматрао да се поред изучавања историје, као средства моралног васпитања, може користити и општење са људима и наставников пример. Иако је био против моралних поука на ранијим ступњевима, Русо је дао савете о ставовима које треба имати у односу на дете: не заповедати, већ му омогућити да само дође до сазнања о својој слабости, не забрањивати, већ спречавати и тд.

Истакнути педагог Јохан Хајнрих Песталоци у делу Како Гертруда учи своју децу (1946) васпитни циљ дели на три задатка: васпитање главе (умно васпитање), васпитање срца (морално васпитање) и на васпитање руке (физичко и радно васпитање). Песталоци много пажње посвећује моралном васпитању. Највише моралне вредности су у љубави према људима, у доброти, поверењу и послушности. Ове вредности најпре почињу да се остварују у породици, где је улога мајке доминантна, а касније ће школа усавршавати те односе. Сматрао је да ће морално васпитање бити право уколико је засновано на моралној пракси, а не на речима. Зато дете треба да осети врлину, а не само да о њој слуша. 
Јохан Фридрих Хербарт пошао је у своме учењу у нацрту педагошких предавања из 1806. (према: Ценић, Петровић 2005,168) о моралности и моралном васпитању од Канта, али је израдио оригинални педагошки систем у коме је запажено место дао моралном васпитању. Он је своју педагогију засновао на интелектуалистичкој психологији и етици. Хербартов циљ васпитања одликује једнострано интелектуалистичко схватање човека и неодређеност појма "морални карактер", који је Хербарт преузео из етике.

Хербарт сматра да поред управљања и наставе, морално васпитање представља саставни део васпитног процеса. Морално васпитање припрема за будуће самостално понашање. Настава води до васпитања у ужем смислу, а путем тог васпитања остварује се морално васпитање. Морално васпитање треба, пре свега, да формира вољу и карактер будућег члана друштва. Главно место и улогу у његовом систему заузима ангажовање наставника и васпитача, уношењем моралних појмова у сазнања ученика. Хербарт је сматрао да васпитач мора да узме у обзир индивидуалност личности, да проналази у дечјој души оно што је добро и да се ослања на то. Учитељ треба да представља једини ауторитет у погледу моралног васпитања. Због тога је потребно да учитељ буде широко и дубоко образован, моралан и с неопходним педагошким тактом. Он је означио шест практичних начина моралног васпитања: суздржавајући, усмеравајући, нормативни, одмерено јасан, морализаторски и наговарачки начин.

У морал су упрте очи човечанства које је разбило сувише разорних сила, с надом да ће можда он бити онај чинилац који ће моћи укротити силе зла и обезбедити даљи несметани развој. Поставља се питање: да ли ће морал уопште постојати у будућности, и ако неће да ли ће то бити зато што ће човек постићи морално савршенство или зато што ће престати да буде морално биће?

Ако бисмо спровели анкету и поставили питање - Шта је то морал?, добили бисмо комбинацију описа особа, група и ситуација у дијапазону од понашања, навика, ставова, емолција, способности, поступака до најопштије форме вредности и идеологија. Слично овим разликама, кроз историју људског друштва се мењало схватање вредности и морала.

Када проучавамо вредности, видимо да се оне реализују на три нивоа: појединачне вредности, вредносне оријентације и вредносни системи. Први, најнижи ниво су појединачне вредности. То су вредности које човек реализује као властите и најчешће конкретно. Оне могу имати конкретну и општу форму. Конкретна форма би могла бити, на пример, изградити кућу, а општа форма, бити добар човек. Ове вредности не морају бити увек синхронизоване. На пример, неко може настојати да изгради кућу посуђеним новцем који не жели вратити. У том случају ова вредност је анахрона у односу на вредност бити добар човек. Други ниво реализације вредности су вредносне оријентације, односно груписане појединачне вредности које имају исти смер или делују у истом правцу. Ове вредности у групи стреме ка одређеном циљу или циљној оријентацији. Међу тим вредностима нема анахронизма или ако га има, делује благо, тако да не омета смер деловања осталих вредности. Трећи и највиши ниво су вредносни системи. Као у сваком систему, препознајемо систем хијерархије ка сегменᄀтима система који се грана до појединачних вредности. У том смислу поједиᄀначна вредност не може да делује без сагласности централне јединице, она не може бити анахрона осталим вредностима. Историјски гледано, у појединим епохама су доминирали различити вредносни системи. Конкретно, у античко доба препознајемо киничко-стоички вредносни систем, истовремено почињу и историјски настављају доминирати епохама хришћански и хедонистички вредносни системи, а након средњег века препознајемо доминацију интелектуалистичко-идеалистичког и данас прагматичко-културолошког вредносног система. Иако доминирају у појединим епохама, поједини вредносни системи не делују 
изоловано, они се преплићу у међусобном деловању. Конкретно, особа може бити хришћански опредељена а уједно да има неке хедонистичке вредности. У том случају бисмо могли препознати одређене вредносне колизије код појединих особа, или чак у датом друштву.

\section{Преглед теза и дефиницја етике и морала}

Појам етика је изведен из грчке речи етхос, што значи обичај, карактер, ћуд, начин понашања, навика и од појма етхикос што значи моралан. Етика као наука и филозофска дисциплина се бави вредностима, вредносним оријентацијама и вредносним системима. Када се етичка норма преточи у правило понашања, у конкретни акт размишљања, осећања, понашања и деловања, говоримо о моралу. Као пракса етике, морал има четири развојне форме: 1) когнитивну или рационалну, 2) емоционалну, 3) социјалну и 4) радно-акциону (Сузић 2005, 547).

\section{Развојне форме морала}

\begin{tabular}{|l|l|}
\hline Форма или димензија & Приступ, аутор \\
\hline $\begin{array}{l}\text { 1) Когнитивна или } \\
\text { рационална }\end{array}$ & $\begin{array}{l}\text { Развој моралног суђења (Piaget, 1932) Морална свијест, } \\
\text { морално убеђење и уверење (Крнета, Поткоњак и } \\
\text { Поткоњак, 1965) Морална спознаја, морална уверења } \\
\text { (Вукасовић, 1977) Етапе моралног формирања (Кohlberg, } \\
\text { 1984) }\end{array}$ \\
\hline 2) Емоционална & $\begin{array}{l}\text { Морална осећања, воља (Крнета, Поткоњак и Поткоњак, } \\
\text { 1965) }\end{array}$ \\
\hline 3) Социјална & Социјалне компетенције (Goleтап, 1998) \\
\hline 4) Радно-акциона & $\begin{array}{l}\text { Морално поступање, морална пракса (Крнета, Поткоњак и } \\
\text { Поткоњак, 1965) Морално понашање и деловање } \\
\text { (Вукасовић, 1977) }\end{array}$ \\
\hline
\end{tabular}

Морал можемо дефинисати као "скуп (неписаних) правила и обичаја који одре $\neg$ Ђуу међусобне односе људи, облик понашања и одређени облик живота у некој заједници" (Педагошки лексикон 1996, 298). Иако у суштини дефиниције морала налазимо социјални критеријум, прегледом радова аутора (табела - Развојне форме морала), видећемо да је управо та димензија моралности запостављена. Већина аутора наглашава когнитивни аспекат моралности.

Лукић $(1974,120)$ морал формално дефинише као скуп друштвених норми које субјект, као сопствену безусловну обавезу, засновану на добром као самосталној врховној вредности, у моралној ситуацији осећа тренутно, целим бићем, а не само увића разумом, која често врши притисак на његове природне склоности и остварује његово човештво, а за чији прекршај он осећа грижу савести, док друштво на њега примењује спољашње санкције уз истовремени захтев да осећа грижу савести.

Стварањем људских заједница морал се развијао стихијски, али са развојем друштвене свести друштвено схватање морала постепено почиње да бива све више индивидуално схватање-појединац постаје носилац моралног понашања. У циљу процене исправности сопственог моралног суда, човек све више тежи упоређивању са другима око себе, и тражењем објективних критеријума, започиње да се развија етика као критичко 
размишљање о основним критеријумима исправног или неисправног у људском понашању ( Павићевић 1974, 218).

Вукасовић $(1977,18)$ напомиње да се морал огледа као активан однос човека према свету око себе и самоме себи, као активан однос према другим људима, породици, радној и другим организацијама, према друштвеној заједници, домовини, човечанству и његовој култури, према раду, материјалним и духовним вредностима. Такође, огледа се и у вредновању људских хтења и поступака као добрих или лоших. Морал је, дакле, активно обликовање, усмеравање и вредновање личних и туђих поступака.

Као духовна појава морал се схвата као норма (скуп значења), као психичка појава морал је скуп психичких процеса мишљења, осећања итд., а као друштвена појава он је друштвени процес "саопштавања" односних норми. Педагогија, гледајући уопштено, посматра морал као појаву да у људском друштву постоје принципи према којима његови чланови, у мањој или већој мери, обликују своје карактере, намере, мотиве и циљеве, као и поступке, и о њима на основу тих принципа доносе моралне судове (Педагошки речник 1967, 583).

Шушњић говори о четири теорије које објашњавају изворе моралних осећања, моралне свести и понашања. Најпре објашњава теорију нагона или несвесног, према којој у моралним ситуацијама или ситуацијама избора, човека непогрешиво води нагон или његово несвесно. Ако би ова теорија била тачна, наводи Шушњић $(1998,301)$, „онда човек поступајући нагонски или несвесно, не би могао морално да греши. Али искуство показује да он греши, што значи да се у стварима добра и зла не сме препустити нагону“. Рационалистичка теорија сматра да људи морално не греше зато што су зли по природи, него зато што не знају како треба да поступе. Од моралног човека очекује се да морално делује, а не да морално расуђује, он је видљив пример моралне норме која се креће међу људима. Припадници Социологистичких теорија сматрају да је морал глас друштва у нама. Поступак неког члана заједнице не одобрава се зато што је добар, него је добар зато што се одобрава. Тамо где је друштво једини субјект моралног одлучивања и вредновања, губи се лична одлука и одговорност за учињени избор. Према четвртој теорији о натприродном извору морала, сматра се да је морал траг божанске искре у нама. Ако човек поступи неморално, не следи му никаква казна од споља, али следи нужно казна изнутра - грижа савести (Шушњић 1998).

Rest (Rest et al. 1999)и његови сарадници говоре о макро и микро моралу и њиховим разликама. Наиме, према овим ауторима, макро моралнос т подразумева друштвену формалну структуру, која је дефинисана од стране друштвених институција, правила и улога. Под микро моралношћу се подразумева појединачан (лицемулице) однос, који људи имају свакодневно, где се од самих субјеката очекује моралност и делање у складу са неписаним моралним нормама. Када говоримо о моралном деловању, пожељно је поменути и Кантаињегов Категорички императив, који гласи: „Ради увек тако да максима твоје воље постане општи закон.“

Djui (Dewey) истиче да се морал сувише уско схвата. „С једне стране он је обојен сентименталним привидом доброте и не доводи се у везу са стварном способношћу да се учини оно што је друштвено потребно, а са друге, прекомерно се наглашава конвенција и традиција, тако да се морал своди на списак коначно утврђених поступака. Уствари, морал обухвата пођеднако широку област као и поступци који се тичу наших односа са другима““(Djui 1966, 247).

За представника функционалистичке теорије система Николаса Лумана, „морал је изгубљена парадигма“ (Милосављевић 2006, 139). Он моралу одузима значај и функцију будући да није у стању да интегрише целокупно друштво и јер је, како мисли, западни привредни свет потиснуо већ давно моралистичку перспективу. Свет у који се 
примиче оружаној и еколошкој катастрофи, судећи по овим ставовима, морална упозорења, не само да нису пожељна, већ су сасвим сувишна. Насупрот Луману, Будон питањима „да ли је морал у кризи, да ли можемо говорити о сумраку вредности?“ (Гавриловић 2008), даје одговор да не постоји криза вредности, да не постоји дисконтинуитет између модернизма и постмодерности, већ да се ради о продубљивању индивидуализма и да развој вредности иде ка већем поштовању индивидуе. Како то Гавриловићева (2008) објашњава, Будон о дбацује теорије које говоре о кризи и дисконтинуитету вредности у савременом друштву, и тврди да постоји континуитет у остваривању идеје индивидуализма у западној Европии да се не може говорити о сумраку вредности. Он истиче повећање толеранције према различитим моралним вредностима, јер толеранција постаје највећа вредност.

Према Бауману, „постмодернизам можемо схватити као големи трговински центар препунробечијаје главна функција ужитак који нуди сама куповина, егзистенцију која наликује доживотном боравку у трговинскомцентру“. Без великих ауторитета, моралност постаје приватна ствар, а једина потврда исправности сопственог моралног избора може доћи кроз дивљење и реакцију других (Гавриловић 2008, 41).

Етика има специфичан предмет истраживања у чијем средишту су тр иемоције стид, самилос т и поштовање. Стидећи се својих природних нагона и функција сопственог организма, човек показује да он није само то природно матерјално биће, већ је нешто дриго и више. Такође, Големан сматра ( Goleman 1998.), да основни етички ставови у животу зависе од емоција- самоконтроле, борбености, истрајности и самомотивације. По њему постоје две моралне одреднице за којима наше време жуди- то су самосавлађивање и саосећање.

Ђорђевић (1996, 13-14) истиче три основне функције морала: гносеолошку, регулативну и васпитну. Гносеолошка функција морала исказује се у специфичности узајамних односа људи који имају друштвени значај, а јављају се у њиховом непосредном општењу. То се остварује у моралним нормама, погледима, осећањима, поступцима. Регулативна функција морала односи се на уређивање и усклађивање односа човека према човеку, породици, друштву, а њена ефикасност зависи од карактера одређеног друштва. Васпитна функција морала заснива се на свесној, организованој и усмереној делатности којом се код васпитаника формирају пожељни морални квалитети.

Центар овог новог научно- педагошког удубљивања је човек (Сандо 2008) узет као норма свих ствари: са својим обоготвореним знањем и практичним знањем почиње да гледа стварност, стрмоглаво. Равнотежа између црквеног и општег схватања просвете и помесности пружа нам поштовање према традиционалним верским вредностима уз уважавање свега што је савремено оправда- но и откривања општег смисла који води ка општем добру. Ту црквена педагогија има своје видно и кључно место.

У психологији морала већина аутора сматра да је моралност стечена димензија, мада има и аутора који размишљају да моралност зависи и од биолошких диспозиција. Особе се у основи понашају према сопственим интересима и основа алтруистичног понашања у крајњем збиру је последица процене користи по самог појединца. Психологија морала бави се генезом моралне свести, савести, мишљења, понашања као и етапама кроз који индивидуа пролази у развијању сопствене моралности. Људи се разликују у погледу лепоте, интелигенције, талента, умешности, али су сви једнаки по томе што су морални субјекти.

На основу бројних значења морала, закључујемо да морал чине правила, норме и вредности по којима се човек свесно практично понаша према себи, окружењу и другим људима, процењује своје и туђе поступке, означавајући их предикатима "добро" или "зло". Морални феномен је врло сложен, што произилази из чињенице да не постоји 
ниједан облик људске праксе, практичне делатности на релацији човек-човек, човекгрупа, човек-држава, човек-природа а да није одређен и моралном нормом. Морални феномен, поред свог општег важења и значења, има и своје специфичне одлике по којима се разликује од других регулативних норми у друштву као што су обичаји, право и религија. Једна од одлика моралног феномена јесте аутономност. Моралне вредности се код сваког појединца формирају кроз процес васпитања и матурације, физичког и психичког сазревања. Једном усвојени морални принципи, правила и вредности, постају слободни, самостални и регулатори понашања појединца у групи и друштву, без обзира на спољашње притиске и санкције. Санкције су само унутарње, у облику свести, самоосуде. Друга одлика морала је свесност и савесност. О моралном избору понашања говори се само онда ако је плод свесне одлуке, ако се личност понаша по савести, без било каквог условљавања или наредбе са стране. Трећа одлика морала је друштвеност. Човек је природно, психолошко, али пре свега друштвено биће. Он није просто бачен у друштвену заједницу већ је и производ те заједнице са одговарајућим стандардом културе и цивилизације. У тој заједници се и обликују моралне особине које појединцу омогућавају успешно деловање и процену шта је то добро а шта рђаво, за њега и друштво у коме живи. И у совјетској литератури наилазимо на разлике при одређивању појмова морал и моралност. Поједини аутори, Рувинскй, Ињине, Савина $(1981,82)$, одређују морал као облик друштвене свести а моралност као област у којој делују практичне норме понашања. Понекад се под моралом подразумева институција друштвено контролисаног деловања на личност, а под моралношћу мотиви добровољног и одговорног понашања које је засновано на личној свести.

Морал обухвата: обичаје, смернице и норме понашања, моралне категорије, вредности, идеале, практично поступање у складу са нормама, оцењивање својих и туђих поступака, вредносно процењивање. Моралне норме су основни регулатор односа међу људима, настале из практичне људске делатности, практичних људских односа, људског обликовања света- из конкретних људских односа у одређеној друштвеној заједници.

Основу за формирање моралне свести, савести и понашања представља морално образовање. Морална сазнања заснована су на разуму. Усвајање знања о моралу представља основ за формирање моралне личности. Јасну дистинкцију између моралног васпитања и моралног образовања направио је Гогола представивши морално образовног човека као личности "која има разумски изграђен систем морала, јасне појмове о моралним вредностима, зна објективно да расуђује о моралним питањима, зна разумски да решава моралне проблеме..." док је морално васпитаног човека својим доживљајем приближио свету моралног, "морално васпитан човек настоји да морално уздигне себе самог, своју средину и друштво, у свом карактеру изгради моралне особине и моралне идеале"(Gogola 1964, 256).

Када се у педагогији говори о моралном аспекту педагошког деловања на развој личности, не мисли се на учење одређених лекција из морала, већ на истицање сврхе моралног деловања, на истицање мотива за морално деловање и оспособљавање за процењивање моралних вредности. Морално деловање засновано је на моралној свести која је први и основни услов моралности. Морална свест не настаје сама од себе. За формирање моралне свести потребне су морално вредносне информације и искуство, јер је то особено-вредносна карактеристика сваке индивидуе. Сврха моралног деловања све више истиче потребу оспособљавања личности за толеранцију, за живот у интеркултуралној заједници у мултикултуралном друштву, за живот у плуралном друштву-друштву мноштва различитог морала и различитих моралних вредности (Milat 2005, 123). 
Нама остаје да преиспитамо и утврдимо значајне васпитне поступке за морално деловање и оспособљавање, који ће утицати на развијање аутономије личности. Требало би разјаснити - какву ми то личност желимо да развијемо а какву заиста и добијамо у постојећем систему васпитања и образовања? Питања о православном васпитању се на концу своде на једно; на који начин васпитавати савремено дете у савременом свету, како му помоћи да пронађе "пут, истину и живот", и на који начин педагог може стећи духовну дисциплину, захваљујући којој ће бити истински помоћник младима у њиховом духовном узрастању? На питање о садржају Православна педагогија (Игуман Георгије Шестун 2013), игуман Георгије даје једноставан и простодушан одговор: православна педагогија је педагогија чији циљеви нису ограничени оквирима човековог земаљског живота, већ иду изван њих, у живот вечни; православна педагогија је педагошка пракса која се темељи на Православној Цркви и налази ослонац у њеним светим тајнама.

\section{Закључак}

Поглед на педагошку панораму нашег времена кроз призму хришћанских и етичких постулата суочава нас са мноштвом отворених питања, егзистенцијалних недоумица и страхова од краја цивилизације нарочито када медијском сценом "дефилују" слике и феномени зла, сумрака разума и морала, злочини као константна стварност, са којом се саживљавамо. Урушавање релевантних друштвених система и институција у атмосфери данашњег друштва, савременог света, директно и индиректно производе моралну кризу, ерозију етичких императива и норми, чије последице су погубне за развој младих генерација и будућност друштва. Етика православних хришћана (Живковић 2018) полази од питања како изаћи на крај са собом, са својом неумереношћу, са својом пожудом, похлепом, са својим негативностима, са својом љутњом, са својим осећајем празнине и бесмисла, са својом надменошћу. Ова стања душе одраслих јесу оно што стварно угрожава децу у заједничком животу са њима. Под претпоставком да је човек сам немоћан да изађе на крај са овим духовним слабостима и поремећајима, пресудну важност има његова вера. И она је пресудна првенствено у том смислу. Однос са Богом у кога верујемо, или са оним у шта верујемо, је референтан нашем односу са ближњима, у овом случају нашем односу са децом. Савремена цивилизација директно и индиректно производи моралну кризу, ерозију етичких императива и норми, чије последице су са манифестацијама против човека и човечног. Она је напредовала у научно-техничкој и технолошкој области, а заостала у хуманистичком делу. Стога је дошло до угрожавања свих најбитнијих вредности човека и морално-хуманих норми живљења, па је неопходно да се успоставе морално-хумани цивилизацијски односи у свету. Неопходно је да се ради на валоризацији прошлости у области морала и хуманизма и сачувају трајне вредности које би се дограђивале активношћу личности и људских заједница.

Истицање хришћанских вредности хуманизма за добро човека и његове социјалне средине значи избегавање конфликтне ситуације, а подизање знања увећава сопствене вредности и доприноси вредностима других. Потребно је супротстављати се духовном насиљу које се остварује моћним и све моћнијим масмедијима којима се служе конзервативни друштвени слојеви за ширење лажи и песимизма, за пропагирање вештачких потреба, живота без рада, безнађа, начина живота потрошачког друштва, неморала и понашања којима се неће поштовати суштина друштвених, моралних, правних и хуманих норми.

Наша будућност је оно што је најдрагоценије и најскупоценије, а то је рад са младима и за младе, као најплеменитији чин човека и човечанства. Наш хумани позив и ангажман, сија новом снагом, вером у моћ знања нас, педагошких иноватора, који смо 
дужни да пренесемо на наше васпитанике. Увек нам треба бити на уму да сваки наш васпитаник носи у себи једну или више даровитости, шансе да буде хришћанско-морална личност. Данас и мали кораци имају висока достигнућа, а ствараоци реноме реформатора. Ми, педагошки иноватори, рефлекторима свога ума и својом педагошком етиком треба да осветљавамо праве вредности и путеве будућности. Данас васпитаницима много дугујемо на овој цивилизацијској ветрометини.

\section{Литература} уметности.

1. Вукасовић, А. (1977): Моралне квалитете наших ученика. Загреб: Израз и

2. Гавриловић, Д. (2008): Морал и религија у савременом друштву. Ниш: Филозофски факултет.

3. Гогола, С. (1964): Навикавање и васпитање. Београд: Просвета.

4. Goleman, D. (1998): Working with emotional intelligence. New York: Bantam Books.

5. Djui, DŽ. (1936): Морал и васпитање. Скопље: "Немања".

6. Ђорђевић, J. (1996): Аутономија личности и васпитање. Београд: Зборник " Аутономија личности и васпитање ", Институтзапедагошкаистраживања, 5-15.

7. Живковић, И. (2018): Пустите деиу, гледајте себе. Аутографи. Ву Поуке.орг инфо.

8. Игуман Георгије Шестун. (2013): Православна педагогија. Каленић.

9. Коменски. Ј. А. (2000): Материнска школа. Београд: Завод за уџбенике и наставна средства.

10. Лок. Џ. (1967): Мисли о васпитању. Београд: Завод за издавање уџбеника социјалистичке Републике Србије.

11. Лукић, Р. (1976): Социологија морала. Београд: Научнакњига.

12. Milat, J. ( 2005 ): Pedagogija - teorija osposobljavanja. Zagreb: Školska knjiga.

13. Милосављевић, Љ. (2006): Увод у филозофију. Ниш: Пунта.

14. Митрополит Иларион Алфејев (2009): Беседе о хришћанском животу-превод са руског језика. Краљево.

15. Павићевић, В. (1974): Основи етике. Београд: БИГЗ.

16. Педагошки лексикон (1996): Београд: Завод за уџбенике и наставна средства.

17. Педагошки речник 1 и 2 (1967): Београд: Завод за издавање уџбеника СР Србије

18. Песталоци, J. (1946): Како Гертруда учи своју деиу. Београд: Просвета.

19. Радовић Амфилохије, епископ (2002): Основи православног васпитања. Цетиње: Светигора.

20. Rest, J. (1999): A Neo-Kohlbergian approach: The DIT and shema theory. Educational psychology review, 11 (4), 291-324.

21. Рувинскй, Л. И. (1981): Нравственно евоспитание личности. Москва: Издатеыство Московского университета.

22. Русо, Ж. Ж. (1953): Емил или о васпитағу. Београд: Знање.

23. Сандо, Д. (2008): Подвиг спасења као задатак ирквене педагогије. Иновације у настави - часопис за савремену наставу, вол. 21, бр. 4, стр. 21-29.

24. Сузић, Н. (2005): Педагогијаза ХХИ вијек. БањаЛука: ТТ-Центар.

25. Хорачек, Д.(2020): Одгојна димензија упута за исправно живљење у ђелу Обрана Сократова, Факултет за одгојне и образовне знаности, Славонски Брод.

26. Шушњић, Ђ. (1998): Религија II. Београд: Чигоја.

27. Ценић, С. \& Петровић, Ј. (2005): Васпитање кроз историјске епохе. Врање: Учитељски факултет. 


\section{Bisera Jevtić}

\section{MORAL AS A PRACTICE OF PEDAGOGICAL ETHICS}

In this text, the author considers morality as a practice of pedagogical ethics in the spirit of Christian teaching. The complexity of the term is best illustrated by the knowledge that the history of morality is as long as the history of society and that it has transformed and become more complex with the development of society. In this paper, we will deal with the phenomenon of morality through the analysis of several aspects and dimensions that are in the service of pedagogical ethics. Pedagogy is one of those sciences that offer a wealth of ideas and the realization of universal value on how to raise a child, help him preserve human essence and dignity - and how to be a humanistic-moral person today. The child is a space research topic, a permanent subject of education for life's struggle, for moral sublimity, philanthropy, patriotism and freedom-loving. 